\title{
The Nexus Between Openness and Energy Consumption in Shandong Province of China
}

\author{
LI Xiao-ping \\ Economics and Management College \\ Weifang University \\ Weifang, Shandong, China \\ E-mail: wfliping1963@163.com
}

Keywords: Energy consumption, Import and export, FDI, International Tourists

\begin{abstract}
Based on the data over 1998-2017 of Shandong province in china, this paper examines nexus of openness and energy consumption from regional perspective. The cointegration equations indicate the export and international tourists arrivals are positively correlated with the energy consumption, while import and FDI are negatively. But the Granger causality test results show that none of the openness factors is Granger causality of energy consumption. Then we can get conclusion that the openness hasn't raise energy consumption, and the open economic activities are environmentally friendly. The local government should implement incentive policies to promote FDI, foreign trade and tourism development.
\end{abstract}

\section{Introduction}

After around 40 years reform and opening up to the world, China has become the second largest country on GDP and almost the biggest foreign trade country in the world. The scale of import, export, inward international tourists and inward foreign direct investment to China has increased greatly and made big contributions to Chinese economy development. While, at the same time, China also has become the biggest energy-consumption country in the world and suffering great environmental pollution. To promote sustainability of energy use, china has enforced many macroplans, such as The Energy Development Strategy Action Plan of 2014-2020, the Electric Power Development and Medium- and Long-Term Development Plan for renewable energy. China is strictly abiding by the carbon dioxide emission reduction commitments of the Paris Convention and have adopted many countermeasures to actively promotes the implementation of environmental protection policies.

Weidmann (2013) noted that for the rising world economy, many studies are of the view that energy consumption and pollution emission can be transferred as well as goods and services along the supply chains in cross-boundary commercial activities [1]. This paper is supposed to examine the causal linkage between energy consumption and some openness factors, such as export, import, FDI and tourists arrivals.

\section{Literature review}

In economic literature, researchers have extensively studied the impact of international trade and FDI on environment, and the race-to-the-bottom hypothesis and the pollution haven hypothesis are well known. But some researchers remain positive attitude to the environmental effect of free trade and inward FDI. Jeffrey A. Frankel and Andrew K. Rose (2005) recognized the possibility of an effect which is called the gains-from-trade hypothesis and they believe openness could have a positive effect on environment [2].

Some studies have focused on the causality nexus of economic growth, trade openness and energy consumption. Menyah and Wolde-Rufacel (2010) found that a unidirectional causality from carbon emissions and energy consumption to economic growth and from energy consumption to carbon emissions [3]. Eleazar Zerbo (2017) found that the trade openness enhances economic 
growth and is not linked to causing carbon emissions in14 Sub-Saharan African countries, hence a trade incentive policy may be implemented without harmful effect on the quality of the environment [5].

As many researches support the conclusion that energy consumption is the causality of carbon emissions in some countries. Based on this hypothesis, it is a reasonable method to examine the inter-relationship between energy consumption and trade, international tourists and FDI if we want to learn the environmental effects brought by such openness factors. Eleazar Zerbo (2017) believes that as each country has its specific characteristics and its economic structure, this kind of study should implement at the country level [5]. Considering China is a big country with complicated geographical features, different economic development level areas, it will make more sense to study the nexus between energy consumption and openness from a specific area.

\section{Choice of Data}

The standard annual time series during 1995-2017 of Shandong Province of China on foreign direct investment, the import and export volume, the international tourists and energy consumption are collected. All original data come from Shandong Provincial Bureau of Statistics net and Department of Commerce of Shandong Province net. Energy consumption is proxied by total energy use per capita, named as ENGY. Data on import and export are proxied by the ratio of import and export volume to GDP respectively, named as IMP and EXP. FDI is the Foreign direct investment to GDP and TOUR represents international tourist arrivals to Shandong Province. As the natural logarithm transform of variables can eliminate heteroscedasticity likely existed without affecting their relationship, the logarithmic transformation of initial variables is applied to this analysis. Finally, we get the time series LNENGY, LNFDI, LNIMP, LNEXP, LNTOUR. The software Eviews3.1 is applied in this analysis.

\section{Co-integration test of variables}

\subsection{Unit Root Test}

The Augmented Dickey-Fuller Unit Root Test method is commonly used before cointegration test in order to avoid spurious regression in the analysis of non-stationary time series, and table1 shows the results.

Table1: Augmented Dickey-Fuller Unit Root Test Result (ADF test)

\begin{tabular}{l|l|l|l|l|l}
\hline Variables & $\begin{array}{l}\text { Test Type } \\
(\mathrm{C}, \mathrm{T}, \mathrm{K})\end{array}$ & $\begin{array}{l}\text { ADF Test } \\
\text { Statistic }\end{array}$ & $\begin{array}{l}5 \% \\
\text { Critical } \\
\text { Value }\end{array}$ & $\begin{array}{l}10 \% \\
\text { Critical } \\
\text { Value }\end{array}$ & Results \\
\hline LNENGY & $(\mathrm{C}, \mathrm{T} 1)$ & -1.8270 & -3.6454 & -3.2602 & $*$ \\
\hline LMEXP & $(\mathrm{C}, \mathrm{T}, 1)$ & -1.0957 & -3.6454 & -3.2602 & $*$ \\
\hline LNIMP & $(\mathrm{C}, \mathrm{T}, 1)$ & -1.7921 & -3.6454 & -3.2602 & $*$ \\
\hline LNFDI & $(\mathrm{C}, \mathrm{T}, 1)$ & -2.3156 & -3.6454 & -3.2602 & $*$ \\
\hline LNTOUR & $(\mathrm{C}, \mathrm{T}, 1)$ & -0.4799 & -3.6454 & -3.2602 & $*$ \\
\hline DLNENGY & $(0,0,1)$ & -1.3713 & -1.9592 & -1.6246 & $*$ \\
\hline DLMEXP & $(0,0,1)$ & -3.1076 & -1.9592 & -1.6246 & $* *$ \\
\hline DLNIMP & $(\mathrm{C}, \mathrm{T}, 1)$ & -3.6051 & -1.9592 & -1.6246 & $* *$ \\
\hline DLNFDI & $(0,0,1)$ & -2.3116 & -1.9592 & -1.6246 & $* *$ \\
\hline DLNTOUR & $(0,0,1)$ & -0.9859 & -1.9592 & -1.6246 & $*$ \\
\hline DDLNENGY & $(0,0,1)$ & -3.6149 & -1.9602 & -1.6251 & $* *$ \\
\hline
\end{tabular}

Note: $\mathrm{C}, \mathrm{T}$ and $\mathrm{K}$ in test type $(\mathrm{C}, \mathrm{T}, \mathrm{K})$ denotes intercept, trend and the lagged differences included in the test equation respectively. ${ }^{*}$ and $* *$ donate the time series are (aren't) stationary at $5 \%$ significance level.

From the results in Table1: at 5\% significance level, all of these series aren't stationary. But, at the first-order difference, the time series of DLNFDI, DLNIMP, DLNEXP are stationary. At the second-order difference, the time series of DDLNENGY, DDLNTOUR are stationary. So LNFDI, LNEXP, LNIMP are the same stationary I (1) process, and LNENBY and LNTOUR are the same 
stationary I (2) process. It is feasible to make further co-integration test among DLNENGY, LNFDI, LNIMP, LNEXP, and also, between LNENGY and LNTOUR.

\subsection{CO-INTEGRATION TEST}

\subsubsection{Co-integration test of DLNENGY, LNFDI, LNIMP and LNEXP}

The Johansen test allows to reveal existence of static linear combinations of time series and has been applied widely. The Johansen test results are shown in table2.

Table2: Cointegration Rank Test

\begin{tabular}{c|c|c|c|c}
\hline Eigenvalue & $\begin{array}{c}\text { Likelihood } \\
\text { Ratio }\end{array}$ & $\begin{array}{c}5 \text { Percent } \\
\text { Critical Value }\end{array}$ & $\begin{array}{c}1 \text { Percent Critical } \\
\text { Value }\end{array}$ & $\begin{array}{c}\text { Hypothesized } \\
\text { No. of CE(s) }\end{array}$ \\
\hline 0.7219 & 58.7649 & 47.21 & 54.46 & None ** \\
\hline 0.5785 & 33.1729 & 29.68 & 35.65 & At most ${ }^{*}$ \\
\hline 0.3958 & 15.8921 & 15.41 & 20.04 & At most ${ }^{*}$ \\
\hline 0.2523 & 5.81487 & 3.76 & 6.65 & At most 3 \\
\hline
\end{tabular}

Notes: $*(* *)$ denotes rejection of the hypothesis at $5 \%(1 \%)$ significance level. L.R. test indicates 4 cointegrating equation(s) at $5 \%$ significance level. The lag period is 1.

L.R. test indicates there are 4 cointegrating equations at $5 \%$ level, so there is long-term stable equilibrium relationship among the variables. The cointegrating equation is as the following:

DLNENGY=-1.4603+2.0179 LNEX-1.6493 LNIMP-0.1053 LNFDI

The positive coefficient of LNEXP in the equation indicates that export promotes energy consumption, which means Shandong Province exported energy-intensive products which could be averse to the environment. But the negative coefficients of LNIMP and LNFDI indicate import and inward FDI have beneficial environmental effects.

\subsubsection{Co-integration test of LNENGY and LNTOUR}

The Johansen test method is applied to run the cointegration test of LNENGY and LNTOUR, and the results are in the following table3.

Table3: Cointegration Rank Test

\begin{tabular}{c|c|c|c|c}
\hline Eigenvalue & $\begin{array}{c}\text { Likelihood } \\
\text { Ratio }\end{array}$ & $\begin{array}{c}5 \text { Percent } \\
\text { Critical Value }\end{array}$ & $\begin{array}{c}1 \text { Percent Critical } \\
\text { Value }\end{array}$ & $\begin{array}{c}\text { Hypothesized } \\
\text { No. of CE(s) }\end{array}$ \\
\hline 0.429794 & 18.62055 & 15.41 & 20.04 & None $^{*}$ \\
\hline 0.308761 & 7.385401 & 3.76 & 6.65 & At most $1 * *$ \\
\hline
\end{tabular}

Notes: $*(* *)$ denotes rejection of the hypothesis at $5 \%(1 \%)$ significance level. L.R. test indicates 2 cointegrating equation(s) at $5 \%$ significance level. The lag period is 2 .

L.R. test indicates there are 2 cointegrating equations at $5 \%$ level, so there is long-term stable equilibrium relationship between LNENGY and LNTOUR. The Normalized Cointegrating Equation is: $\mathrm{LNENGY}=0.677158+0.583098^{*} \mathrm{LNTOUR}$

The positive coefficient of LNTOUR in the equation indicates that international tourists arrival leads to high energy consumption.

\section{Granger Causality Tests}

As Granger Causality Test requires all time series are stationary, so we get five new series using the difference method: DDLNENGY, DLNEXP, DLNIMP, DLMFDI, DDLNTOUR. The results are shown in table4. This result suggests that DLNEXP, DLNIMP, DLNFDI and DDLNTOUR are not Granger Cause of DDLNENGY. 
Table 4: Pairwise Granger Causality Tests

\begin{tabular}{c|c|c|c}
\hline Null Hypothesis: & Obs & F-Statistic & Probability \\
\hline $\begin{array}{c}\text { DLNEXP does not Granger Cause } \\
\text { DDLNENGY }\end{array}$ & 20 & 0.00254 & 0.96041 \\
\hline $\begin{array}{c}\text { DLNIMP does not Granger Cause } \\
\text { DDLNENGY }\end{array}$ & 20 & 0.40493 & 0.53303 \\
\hline $\begin{array}{c}\text { DLNTOUR does not Granger } \\
\text { Cause DDLNENGY }\end{array}$ & 20 & 0.36690 & 0.55270 \\
\hline $\begin{array}{c}\text { DLNFDI does not Granger Cause } \\
\text { DDLNENGY }\end{array}$ & 20 & 0.97451 & 0.33740 \\
\hline
\end{tabular}

\section{Conclusion and suggestion}

Based on the data over 1998-2017 of Shandong province in china, this paper examines nexus of openness and energy consumption. The cointegration equations indicate the export volume of Shandong province and international tourists arrival are positively correlated with the energy consumption, while import and FDI are negatively. But the Granger causality test results show that none of the openness factors is Granger causality of energy consumption. Then we can get conclusion that the openness hasn't raise energy consumption, and the open economic activities are environmentally friendly. This conclusion is different from that of Edmund Ntom Udemba(2019), as they believe tourism arrivals have a bi-directional causal relationship with energy consumption. But this conclusion is similar to that of Eleazar Zerbo, who got conclusion that trade openness enhances economic growth and is not linked to causing carbon emissions in sub-Saharan African countries.

Based on some researchers' conclusion that more energy consumption leads to more carbon dioxide emissions, the export of Shandong province is not energy-intensive products and the import is not leading to increase of energy consumption, so the trade in Shandong province is environmental friendly and the local government should keep promoting foreign trade development The FDI promotes economy development but not the Granger cause of energy consumption. So FDI incentive policy may be implemented without harmful effect on the quality of the environment. Developing international tourism vigorously and attract more international tourists to Shandong should be a consistent policy without worrying about environment issues.

\section{References}

[1] Weidmann, N.O., Transformation strategies towards a sustainable Swiss energy system: An energy-economic scenario analysis (Doctoral dissertation, ETH Zurich),2013

[2] Jeffrey A. Frankel and Andrew K. Rose. Is Trade Good or Bad for the Environment? Sorting out the caudality, The Review of Economics and Statistics, 87(1): 85-91, February, 2005

[3] Menyah and Wolde-Rufacel. Energy consumption, pollutant emissions and economic growth in South Africa, Energy Economy, 32(6):1374-1382,2010

[4] Farhani S. Chaibi A. Rault C. $\mathrm{CO}_{2}$ emissions, output, energy consumption, and trade in Tunisia, Economy Modelling, 38:426-434, January 2014

[5] Eleazar Zerbo, Income-environmental relationship in Sub-Saharan African Countries: Further evidence with trade openness, Environment Science Pollution Research,24:16488-16502, 2017 